\title{
ASSESSMENT OF POLLUTION-INDUCED DISSOLVED OXYGEN VARIATION IN RIVER CHALLAWA
}

\author{
T. A. Adedokun ${ }^{1, *}$ and J. C. Agunwamba ${ }^{2}$ \\ 1,* Department of Civil EngineEring, Bayero University Kano, Kano State. NigERIA. \\ 2 DEPARTMENT OF Civil ENGinEERING, UNiVERSiTy OF NigERIA, NSUKKA, ENUGU STATE. NIGERIA. \\ Email addresses.1timdok@yahoo.com,2nwambaagu@yahoo.com
}

\begin{abstract}
The study is aimed at investigating the effect of industrial effluents on the water quality of River Challawa. Chemical analyses of samples of the river water collected at predetermined sampling points along a $10.644 \mathrm{~km}$ stretch were undertaken and the observations were subjected to ANOVA and regression analyses. The results obtained indicated that the $D O$ values ranged from $2.4 \mathrm{mg} / \mathrm{l}$ to $1.9 \mathrm{mg} / \mathrm{l}$, while the $B O D_{5}$ ranged from $443 \mathrm{mg} / \mathrm{l}$ to $1654 \mathrm{mg} / \mathrm{l}$; the COD ranged from $1296 \mathrm{mg} / \mathrm{l}$ to $4565 \mathrm{mg} / \mathrm{l}$. The self-purification factor (f) for the River Challawa varies between 0.40 per day and 0.56 per day which puts the river in the sluggish stream category and as a heavily polluted stream. The predictions indicated significant relationship with the observed values at 95\% level of significance.
\end{abstract}

Keywords: River, pollution, effluents, modelling, self-purification factor.

\section{INTRODUCTION}

River Challawa is an important resource which supplies water for irrigation, drinking after treatment, agricultural and fishing activities. It is true that selfpurification processes which occur in a stream enable it to safely handle some wastewater discharges; there is however a limit to its assimilation capacity. The indiscriminate discharge of waste water effluents and municipal sewage into the river may impact negatively on the health of aquatic organisms. For a safe sustainable environment, there is a need for a proper assessment of streams and rivers in Nigeria to ensure control of waste discharge within a stream assimilation capacity which will subsequently result in improved water quality and optimum utilization [1]. The study is composed of three (3) major aspects:

The first aspect is the reconnaissance survey and field work for the gathering of in-situ information on Dissolved Oxygen, the acquisition of raw wastewater effluent sample for BOD, COD, TDS analysis as well as information on other hydrodynamic factors such as stream velocity, depth and width. The sampled reach was limited to $10.644 \mathrm{~km}$ from the upstream at Yandanko to the downstream at Tamburawa.

The second aspect was the laboratory analysis of the industrial effluents for physical, chemical and bacteriological characteristics. The laboratory analyses were carried out at the Water Resources/ Environmental Engineering Laboratory, Department of Civil Engineering, Bayero University and the Kano State Pollution Laboratory, Farm Centre, Kano.

The final aspect was the development of the $\mathrm{k}_{2}$ model establishing the relationship between the parameters and developing the Oxygen sag curve for the area investigated based on the data collected.

\section{METHODOLOGY}

The study was carried out from three different areas, located between longitude $8^{\circ} 22^{\prime} \mathrm{E}$ and $8^{\circ} 33^{\prime} \mathrm{E}$ and latitude $11^{\circ 5} 9^{\prime} \mathrm{N}$ to $11^{\circ} 52^{\prime} \mathrm{N}$, on:

(i) Challawa River with eight sampling stations,

(ii) Waste discharges from effluents in the Sharada Industrial Estate such as the Unique Leather Finishing and others discharging into the Salanta river and flowing through Sabuwar Gandu, Kumbotso and entering the Challawa river at Tamburawa. There were a total number of five sampling points here.

(iii) The third sampling point was from the industries in the Challawa Industrial Estate, made up of Mario-Jones industrial effluent, God's Little industrial effluent, Maimuda industrial effluent, 
Globus industrial effluent and Fata industrial effluent and the confluence of the waste discharges from the Challawa Industrial Estate which finally discharged directly into the Challawa River at Yandanko. There were five sampling points at the Challawa Industrial Estate.

There were eighteen (18 No) sampling points in all. Other industries in the areas include textile industries and a bottling company. Detailed reconnaissance survey of the study area was carried out to ascertain the sampling points. The survey was made by locating the industrial industries in the estates and following the flow through to the points of discharge on Challawa River. Figure 1 shows a schematic view of the study area. A detailed survey of all the points of wastewater discharge into Challawa river were noted and sampling stations designated 1 to 18 were established as explained earlier. Also, Figure 2 is a map of River Challawa showing the sampling points.
Agunwamba et al analyzed the polluted status of Amadi Creek and its management, considering the effect of hydraulic radius in place of the depth of the river at different location, and obtained [2].

$$
K_{2}=11.635 \frac{\mathrm{U}^{1.0954}}{\mathrm{R}^{0.016}}
$$

Ademoroti confirmed in his work that reaeration rate constants $\left(\mathrm{k}_{2}\right)$ depend on the condition of the river. A fast moving shallow stream will have a higher reaeration rate constant than a sluggish stream of stagnant pond or lake [3]. The method used for the computation of reaeration coefficient was based on:

$$
K_{2}=\frac{a V^{a_{1}}}{H^{a_{3}}}
$$

Where $\mathrm{k}_{2}$ is the reaeration coefficient $\left(\right.$ day $\left.^{-1}\right), \mathrm{H}$ is the depth of stream $(\mathrm{m})$ and $\mathrm{V}$ is the velocity of flow $(\mathrm{m} / \mathrm{s})$, a, $a_{1}, a_{2}$ were constants obtained using regression equations.

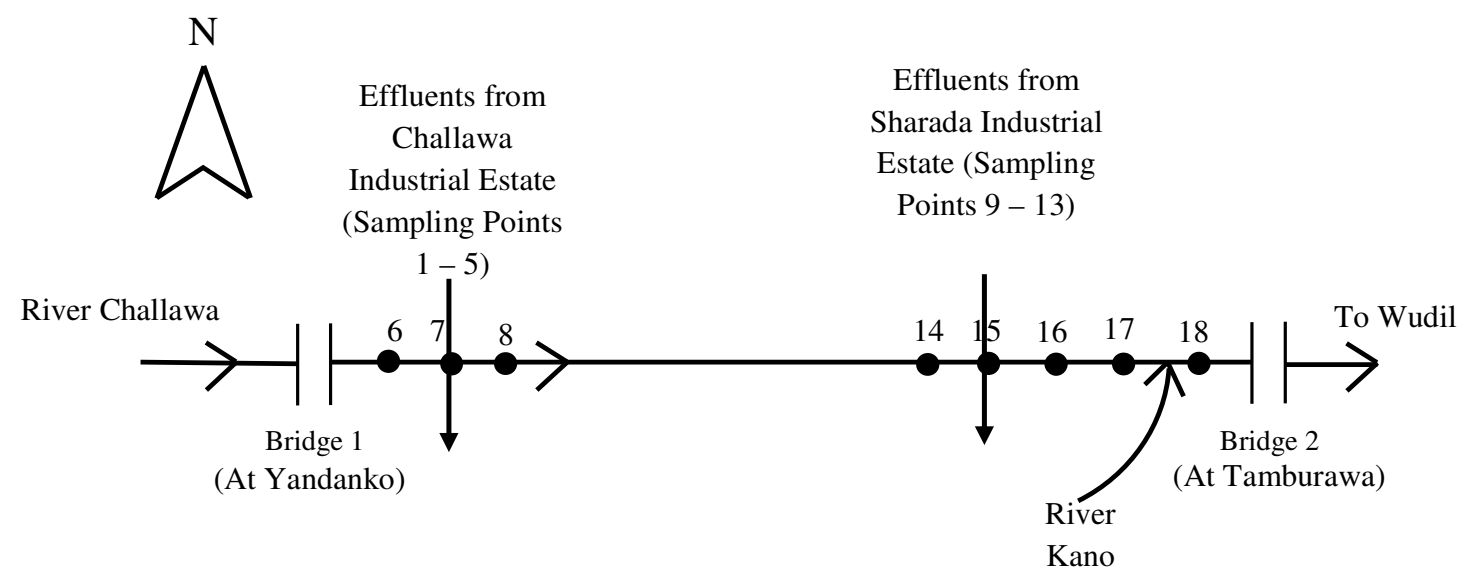

Figure 1: A schematic outline of River Challawa, effluent discharges, sampling points and confluence with River Kano.

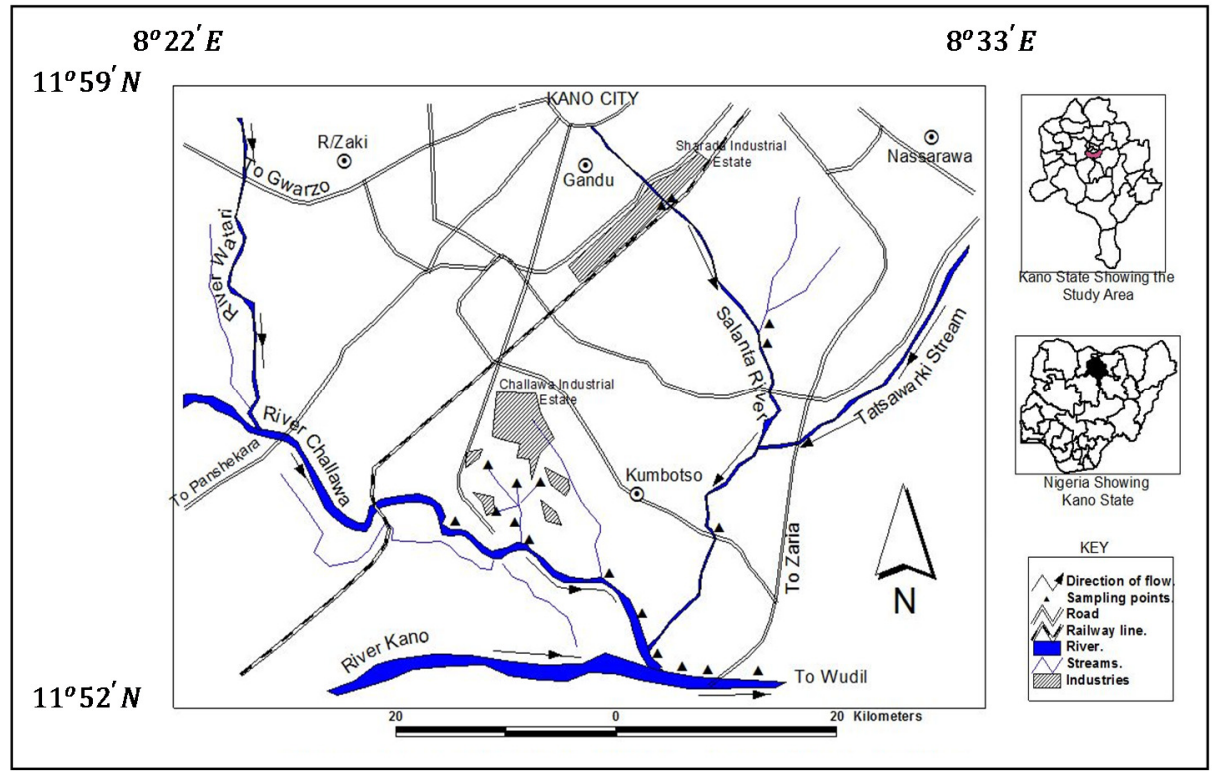

Figure 2: Map of River Challawa showing the sampling points 
Samples for water quality analysis were collected in $1000 \mathrm{ml}$ plastic containers which were initially washed with detergent and rinsed in distilled water. The containers were finally rinsed with diluted sulphuric acid before sampling. Samples were tested immediately but for those that needed preservation, $2 \mathrm{ml}$. of conc. $\mathrm{H}_{2} \mathrm{SO}_{4}$ were added per litre and kept in the refrigerator at $4^{\circ} \mathrm{C}$. Dilutions were carried out as required for samples that were heavily polluted before analysis.

All field meters and equipment were checked and calibrated according to the manufacturer's specifications. The $\mathrm{pH}$ meter was calibrated using buffers of 4.0, 7.0 and 10.0. The Total Dissolved Solid/Conductivity meter was calibrated using potassium chloride solution. $\mathrm{pH}$ and Temperature were carried out using model 4071 meter. Determination of the total dissolved solids and total suspended solids were carried out in the laboratory using the CE 393 digital spectrophotometer. Dissolved oxygen was measured using Jenway 9015 ; chemical oxygen demand was determined by the dichromate digestion method while the biochemical oxygen demand was determined by the dilution method. In situations where measurements have to be taken in-situ, such as dissolved oxygen $\mathrm{pH}$, total suspended solids, spectrophotometer calibrated according to manufacturers' specification were used. The relationship between physicochemical parameters are also observed and presented as Figures 3 - 5 respectively.

\subsection{BOD/COD Parameters}

The BOD/COD relationship shown in Figure 3 is a linear trend with the equation $\mathrm{y}=0.3426 \mathrm{x}+24.579$ and a correlation coefficient of 0.929

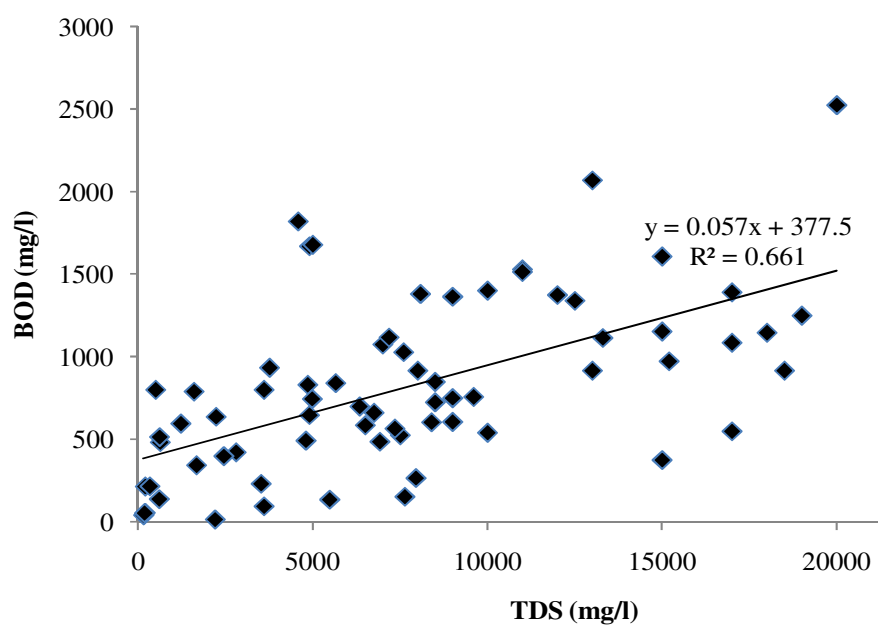

Figure 4: BOD/TDS relationship

\subsection{BOD/TDS Relationship}

The BOD/TDS relationship shown in Figure 4 is a scatter diagram but with a trend line of the equation $y$ $=0.572 \mathrm{x}+377.59$ and a correlation coefficient of 0.661 .

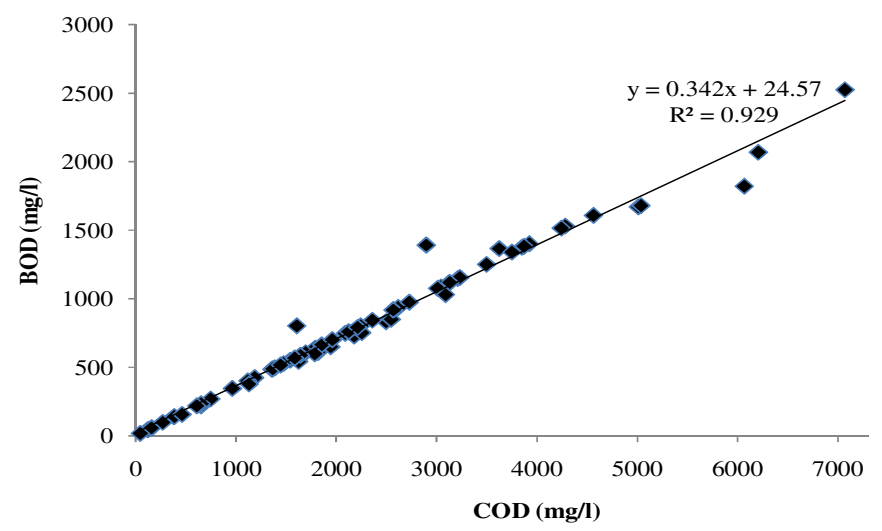

Figure 3: BOD/COD relationship

\subsection{COD/TSS Relationship}

The COD/TSS relationship has the equation $\mathrm{y}=$ $0.1577 x+1025.3$ and a correlation coefficient of 0.618 .

\subsection{COD/TDS Relationship}

The COD/TDS relationship has the equation $\mathrm{y}=$ $0.1565 x+11.09$ and a correlation coefficient of 0.591 .

\subsection{BOD/TSS Relationship}

The BOD/TSS relationship is shown in Figure 5. The trend line equation is $\mathrm{y}=0.0575 \mathrm{x}+547.95$ with a correlation factor of 0.670 . The regression analysis carried out to give correlation coefficient $\mathrm{R}^{2}$ ranged from 0.591 to 0.929 as shown in Table 1. BOD requires a minimum of 5 days incubation before analysis and suffers from poor reproducibility.

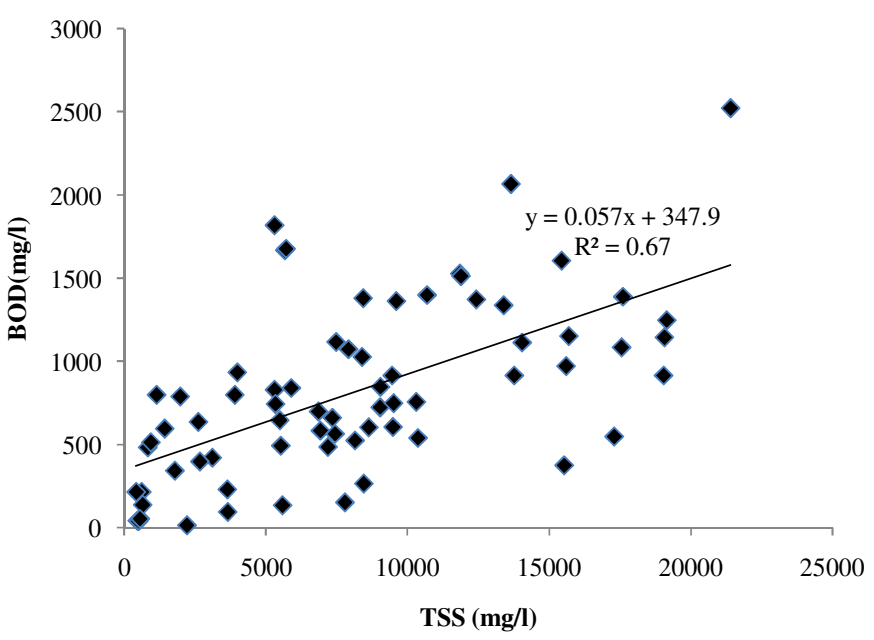

Figure 5: BOD/TSS relationship 


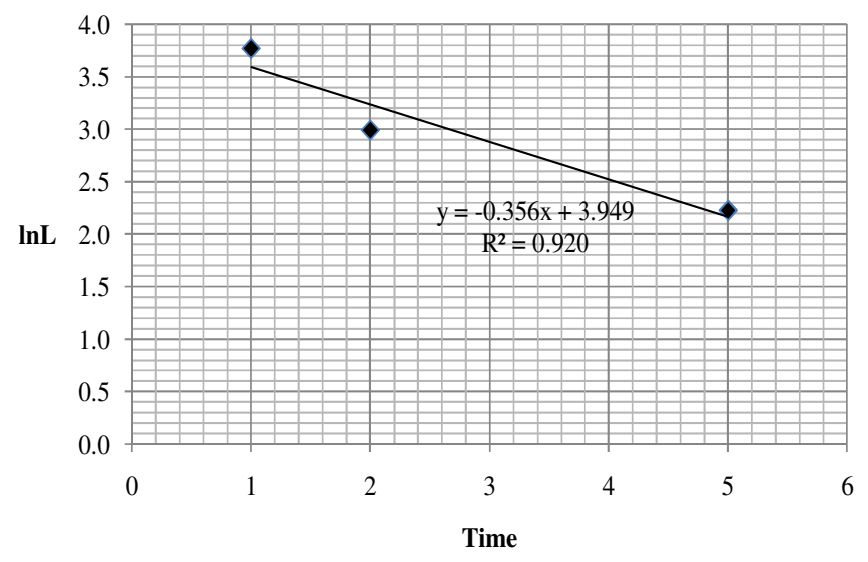

Figure 6: InL versus Time

The other oxidation tests were developed to reduce the time required for analysis in hopes of using these tests for control of wastewater treatment processes. The COD test gave a relatively quick estimation of the carbonaceous contents of the sample (within a matter of 3 hours) compared to the BOD test, which normally takes 5 days.

Table 1: The correlation matrix among the various

\begin{tabular}{lcccc}
\multicolumn{5}{c}{ physico-chemical parameters } \\
\hline & BOD & COD & TDS & TSS \\
\hline BOD & 1 & & & \\
COD & 0.929 & 1 & & \\
TDS & 0.661 & 0.591 & 1 & \\
TSS & 0.670 & 0.618 & 1 & 1 \\
\hline
\end{tabular}

Also the COD test has a higher precision than the BOD test. As polluted water bodies may have a varying proportion of degradable and non- degradable substances in them, the only practical way in which the COD test can be used for estimation of BOD is to develop a specific correlation between COD and BOD values for specific case. The BOD values, observed in industrial wastewater, at various sampling have been plotted against the COD as shown in Figure 3 above. Estimating and modelling the interrelationships between physicochemical pollutants of industrial wastewater such as biochemical oxygen demand is a measure of pollution due to biodegradable organic matter and indicates expected oxygen requirement for water quality improvement. An ecological system under stress has high BOD resulting in oxygen depletion which is not favourable for biological growth. It indicates a degree of anthropogenic source of pollution caused by introduction of sewage or solid waste and is closely associated with other parameters

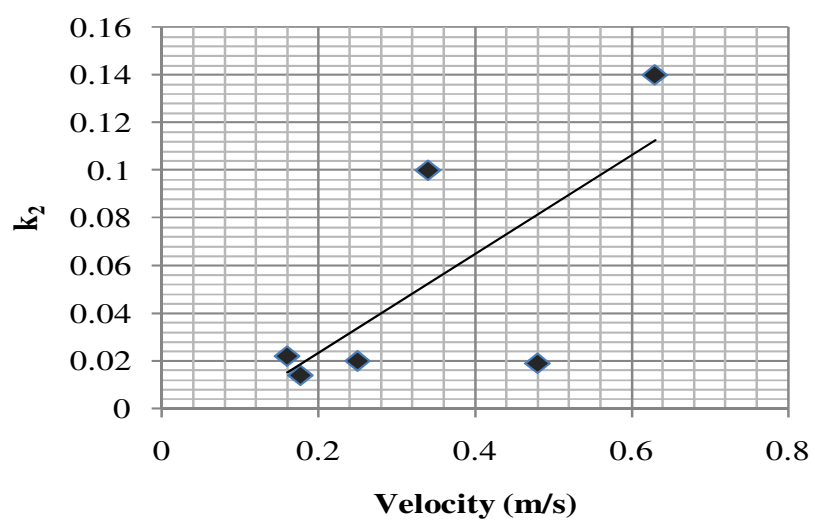

Figure 7: Reaeration coefficient $\left(k_{2}\right)$ versus velocity

like phosphate and nitrate (nutrient) which cause eutrophication (algae bloom), increase biomass and deplete dissolved oxygen during decay of the biomass [1].

Also TSS had a good correlation with BOD but the most significant parameters that impact on BOD was COD as mentioned before. Based on the above results, the study underscores the need for immediate remediation programs to control the discharge of polluted wastewater into Challawa and Sharada rivers. The ratio COD/BOD can be used to assess toxicity of bio-medium. Higher amount implies that the medium has high toxicity. The ratio of COD to BOD does not change significantly and a constant for any particular wastewater. Figure 6 shows the graph of $\mathrm{BOD}_{5}$ versus time used in the measurement of the deoxygenation constant, $\mathrm{k}_{2}[4]$.

\section{CALIBRATION AND VERIFICATION OF THE RE- AERATION MODEL}

Before the calibration was performed, the relationship between $\mathrm{k}_{2}$ and velocity and water depth were explored. The parameter $\mathrm{k}_{2}$ was found to increase as the velocity increases but reduces with decrease in water depth. The plot of $\mathrm{k}_{2}$ versus velocity is shown in the Figure 7 below. Hence, a model of the type $k_{2}=$ $\mathrm{aVb} / \mathrm{H}^{\mathrm{c}}$ was assumed. Calibration of the model showed that it fits the data with $a=0.289, b=1.5464$ and $c=$ 1.5467. Verification of the model with a separate set of data gave a coefficient of correlation 0.8815 .

Prediction of $\mathrm{k}_{2}$ using six of the existing models and comparison with the model of this study gave the following corresponding coefficients of correlation: $0.229,0.295,0.794,0.842,0.0 .676,0.855$, and 0.473 . The corresponding standard errors of estimate are $1.5156,2.3376,0.4216,1.3891,0.0488,0.3854$, and 1.7721. Even though this study did not yield the highest 
coefficient of correlation the standard error of estimate was the least. Table 2 gives the calibration and verification data, while Figure 8 shows the graph of reaeration coefficient $\left(\mathrm{k}_{2}\right)$ versus depth $(\mathrm{H})$ obtained in this study being compared with those obtained by other researchers

\section{PREDICTION OF CHALLAWA RIVER OXYGEN SAG}

The second modification is based on the fact that the reaeration coefficient varies along the river reach as has been presented by previous researchers [8]. Hence, computation of the oxygen sag equation based on an average value of $\mathrm{k}_{2}$ is bound to result in inaccurate prediction.

\subsection{Solution of the Conventional Oxygen Sag Equation}

$$
\frac{d D}{d t}=k_{1} L-k_{2} D
$$

$$
\frac{d D}{d t}=-k L
$$

where

$$
\mathrm{L}(0)=\mathrm{L}_{0} ; \mathrm{D}(0)=\mathrm{D}_{0}
$$

Using Laplace Transformation of (ft) defined by [7]:

$$
L f(t)=\int f(t) e^{-s t} d t
$$

where

$$
\sigma+i \omega=s D(s)-D(0)=\frac{k_{1} L_{0}}{s+k_{1}}-K_{2} D(s)
$$

Where

$$
\mathrm{L}=\mathrm{L}_{0} \exp (-\mathrm{kt})
$$

Table 2: Calibration and Verification Data

\begin{tabular}{|l|c|c|c|c|c|}
\hline Points & $\mathbf{1}$ & $\mathbf{2}$ & $\mathbf{3}$ & $\mathbf{4}$ & $\mathbf{5}$ \\
\hline Velocity $(\mathrm{m} / \mathrm{s})^{\text {Depth, } \mathrm{H}(\mathrm{m})}$ & 0.177 & 0.037 & 0.023 & 0.024 & 0.026 \\
\hline $\mathrm{k}_{2}$ for Dobbins & 1.011 & 0.986 & 0.960 & 0.930 & 1.067 \\
\hline $\mathrm{k}_{2}$ for Churchill 1 $^{\mathrm{b}}$ & 0.090 & 0.001 & 0.000 & 0.001 & 0.000 \\
\hline $\mathrm{k}_{2}$ for Agunwamba & 0.190 & 0.025 & 0.014 & 0.016 & 0.013 \\
\hline $\mathrm{k}_{2}$ for Gualtieri & 1.746 & 0.314 & 0.187 & 0.196 & 0.213 \\
\hline $\mathrm{k}_{2}$ for Churchill Improved & 1.650 & 0.758 & 0.601 & 0.618 & 0.626 \\
\hline $\mathrm{k}_{2}$ for this study & 1.253 & 0.310 & 0.209 & 0.230 & 0.196 \\
\hline
\end{tabular}

a: $\mathrm{k}_{2}=10.046 \mathrm{~V}^{2.696} / \mathrm{H}^{3.902}$ [5], b: $\mathrm{k}_{2}=1.923 \mathrm{U}^{1.325} / \mathrm{H}^{2.006}$ [4], c: $\mathrm{k}_{2}=11.635 \mathrm{~V}^{1.0954} / \mathrm{R}^{0.016}$ for Agunwamba [7], $\mathrm{d}: \mathrm{k}_{2}=3.93 \mathrm{U}^{0.5} / \mathrm{H}^{1 / 5}[6]$, and e: $\mathrm{k}_{2}=5.06 \mathrm{U}^{0.919} / \mathrm{H}^{1.673}(1.024)^{\mathrm{T}-20}$ where $\mathrm{T}=29^{\circ} \mathrm{C}[4]$

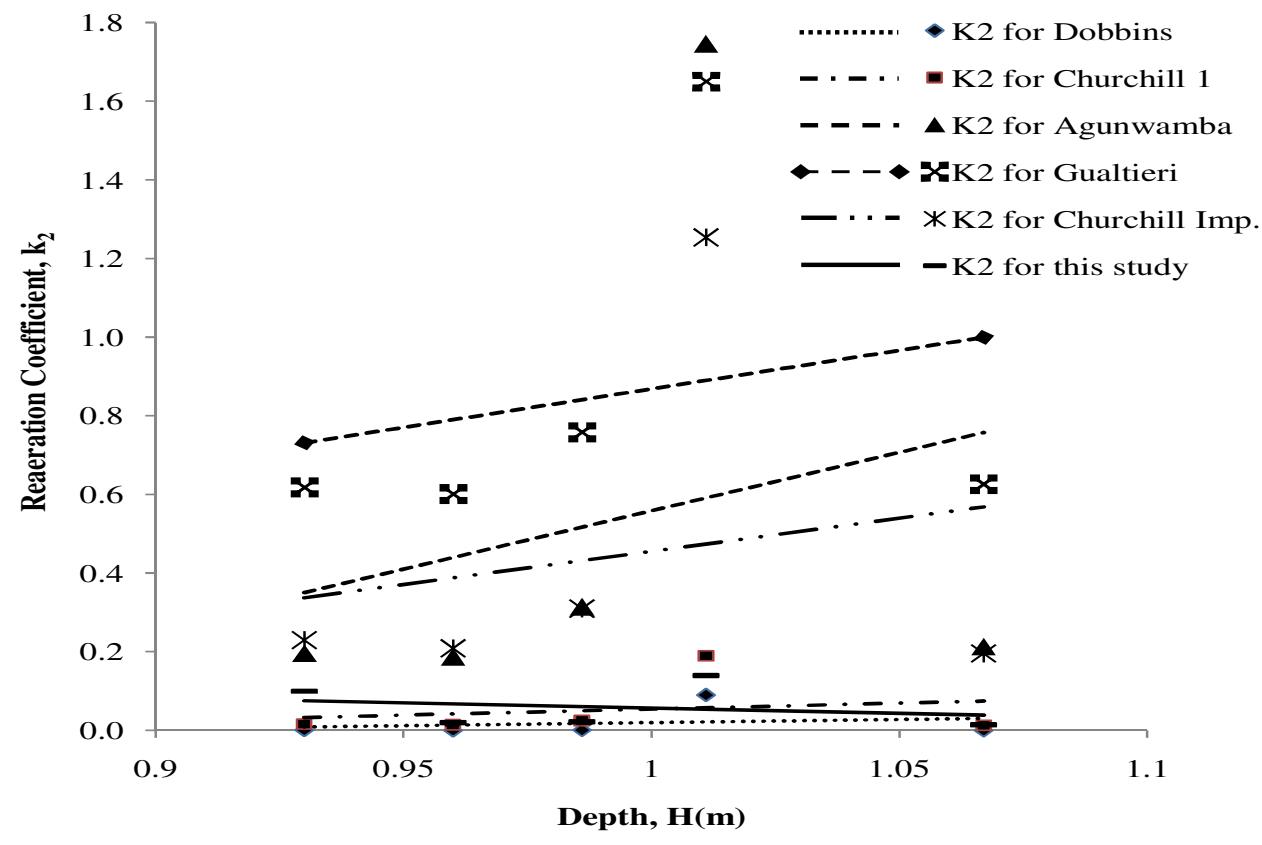

Figure 8: Model Comparisons of Reaeration Coefficients 
Substituting the initial conditions in (8), we obtain

$$
\left(s D(s)-D_{0}\right)\left[s+k_{1}\right]+k_{2} D(s)\left[s+k_{1}\right]=k_{1} L_{0}
$$

After rearranging, it is shown that:

$$
\begin{array}{r}
{\left[s^{2}+s\left(k_{1}+k_{2}\right)+k_{1} k_{2}\right] D(s)=D(s)} \\
=s D_{0}+k_{1} D_{0}+k_{1} k_{0}
\end{array}
$$

From where:

$$
D(s)=\frac{s D_{0}+k_{1} D_{0}+k_{1} k_{0}}{s^{2}+s\left(k_{1}+k_{2}\right)+k_{1} k_{2}}
$$

If equation (11) is resolved into partial fraction, the equation below is obtained:

$$
\begin{array}{r}
D(s)=\frac{A}{S+k_{2}}+\frac{B}{S+k_{1}} \\
W \text { ith } \mathrm{A}=\frac{-\mathrm{D}_{0} \mathrm{k}_{2}+\mathrm{k}_{1} \mathrm{D}_{0}+\mathrm{k}_{1} \mathrm{~L}_{0}}{\mathrm{k}_{1}-\mathrm{k}_{2}} \\
\mathrm{~B}=\frac{\mathrm{k}_{1} \mathrm{~L}_{0}}{\mathrm{k}_{2}-\mathrm{k}_{1}}
\end{array}
$$

Integrating (12) around the appropriate Greenwich contour, $\mathrm{C}$ using the formula

$$
2 \pi i f(t)=\int_{c} e^{s t} f(s) d s
$$

It is clearly shown that:

$$
\begin{aligned}
\mathrm{D}(\mathrm{t})=\mathrm{L}^{-1}[\mathrm{D}(\mathrm{s})] & \\
& =\frac{k_{1} L_{0}}{\left(\mathrm{k}_{2}-\mathrm{k}_{1}\right)\left(\mathrm{e}^{-\mathrm{k}_{1} \mathrm{t}}-\mathrm{e}^{-\mathrm{k}_{2} \mathrm{t}}\right)} \\
& +\mathrm{D}_{0} \mathrm{e}^{-\mathrm{k}_{2} \mathrm{t}}
\end{aligned}
$$

\subsection{Improved Oxygen Sag Equation}

The conventional oxygen sag equation expressed in equations (3) and (4) are modified by incorporating the settling of the industrial waste which occurs along the River reaches. Equation (3) and (16), following the above analysis, may be expanded to include the rate of removal of BOD by benthal decomposition. The resulting relations are:

$$
\frac{\mathrm{dD}}{\mathrm{dt}}=\mathrm{k}_{1} \mathrm{~L}_{0} \mathrm{e}^{-\left(\mathrm{k}_{2}+\mathrm{V}_{\mathrm{s}}\right) \mathrm{t}}-\mathrm{k}_{2} \mathrm{D}
$$

and

$$
\begin{aligned}
& D=\frac{\mathrm{k}_{1} \mathrm{~L}_{0}}{\left[\mathrm{k}_{2}-\left(\mathrm{k}_{1}+\mathrm{V}_{\mathrm{s}}\right)\right]}+\mathrm{D}_{0} \mathrm{e}^{\left(-\mathrm{k}_{2} \mathrm{t}\right)} \\
& =\mathrm{e}^{-\left(\mathrm{k}_{1}+\mathrm{V}_{\mathrm{s}}\right) \mathrm{t}}-\mathrm{e}^{\left(-\mathrm{k}_{2} \mathrm{t}\right)} \\
& +\mathrm{D}_{0} \mathrm{e}^{\left(-\mathrm{k}_{2} \mathrm{t}\right)}
\end{aligned}
$$

Again, equations (3) and (4) are expressed as:

$$
\begin{aligned}
& \frac{d D}{d t}=K_{1} L-K_{2}(t) D \\
\frac{d D}{d t}=- & K L
\end{aligned}
$$

Since $\quad L=L_{0} \exp \left(-k_{1} t\right)$

$$
\frac{d D}{d t}=K_{1} L-K_{2}(t) D
$$

$$
\frac{d D}{d t}=K_{1} L_{0} \exp \left(-k_{1} t\right)-k_{2}(t) D
$$

Obtaining an explicit solution of equation (22), subject to the usual initial conditions, is possible only if the exact function $\mathrm{k}_{2}(\mathrm{t})$ is determined. But $\mathrm{k}_{2}(\mathrm{t})$ is a random variable since it is a function of the depth, flow and wind velocity at each section as well as temperature. In fact, the presence of $\mathrm{k}_{2}$ makes equation (22) a stochastic equation. Hence, for simplicity, we resort to numerical solution.

The finite difference template of equation (17) can be expressed as:

$$
\begin{array}{r}
\frac{D_{i+1}-D_{i}}{\Delta t}=k_{1} L_{o} \exp \left[\left(-\mathrm{k}_{2}+\mathrm{V}_{\mathrm{s}}\right) \mathrm{t}\right]-\frac{\left(k_{2 i+1}+k_{2 i}\right)}{2} . \\
\frac{\left(D_{i+1}-D_{i}\right)}{2}
\end{array}
$$

Re-arranging, we have:

$$
\begin{array}{r}
D_{i+1}\left[1+\frac{\Delta t}{4}\left(k_{2 i+1}+k_{2 i}\right)\right] \\
=D_{i}+\Delta t \cdot k_{1} L_{o} \exp \left[\left(-\mathrm{k}_{2}+\mathrm{V}_{\mathrm{s}}\right) \mathrm{t}\right] \\
+\frac{\Delta t}{4} \cdot D_{i}\left(k_{2 i+1}+k_{2 i}\right)
\end{array}
$$

In (25), $P=\frac{\Delta t}{4} \cdot D_{i}\left(k_{2 i+1}+k_{2 i}\right)$. For unit consistency, $\Delta t$ values attached to $k_{1}$ have to be expressed in minutes.

Table 3 shows the computation data for the oxygen sag at different sections of River Challawa.

By substituting the values of $\Delta \mathrm{t}, \mathrm{Di}, \mathrm{K}_{2 \mathrm{i}}, \mathrm{K}_{2 \mathrm{i}+1}$ and other parameters in equation (29), $\mathrm{D}_{\mathrm{i}+1}$ was obtained. For example, if $\mathrm{t}=0$, then $\Delta \mathrm{t}=0$, the value of deficit dissolved oxygen recorded against row 1 , column 5 was obtained (Table 11).

$$
D_{i+1}=\frac{7.4+0-0}{1}=7.4 \mathrm{mg} / \mathrm{l}
$$

$\mathrm{K}_{1}=0.251$ day $^{-1} ; \mathrm{V}_{\mathrm{s}}=0.157 \mathrm{~cm} / \mathrm{min}$

Table 4 shows the oxygen sag calculations with variable values of reaeration constant $\left(\mathrm{k}_{2}\right)$.

Table 5 shows the measured and predicted values of oxygen sag along River Challawa.

Figure 9 shows the oxygen deficit against distance along Challawa River. Figure 9 shows the trend of oxygen deficit with increased distance along River Challawa showing self purification up to $9 \mathrm{~km}$ where from the upstream where waste industrial effluents are introduced. 
Table 3: Data requirement for computation of oxygen sag

\begin{tabular}{|c|c|c|c|c|c|c|}
\hline Section & Locations along River Challawa & $\mathrm{k}_{2}$ & $\mathrm{C}_{\mathrm{s}}$ & Temperature $\left(\mathrm{T}^{\circ} \mathrm{C}\right)$ & Dissolved Oxygen (C) & $\mathrm{D}_{\mathrm{u}}=\mathrm{C}_{\mathrm{s}}-\mathrm{C}$ \\
\hline \multirow{4}{*}{ 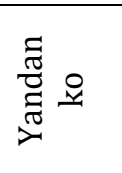 } & Upstream & 0.022 & 7.4 & 30.8 & 2.30 & 5.10 \\
\hline & Point Source & 0.140 & 7.4 & 31.0 & 0 & 7.40 \\
\hline & Downstream & 0.020 & 7.5 & 30.3 & 1.53 & 5.47 \\
\hline & Further Downstream & 0.100 & 7.5 & 30.0 & 2.00 & 5.50 \\
\hline \multirow{5}{*}{ ه } & Upstream & 0.014 & 7.7 & 29.4 & 2.36 & 5.34 \\
\hline & Intermediate point & 0.025 & 7.7 & 29.8 & 3.10 & 4.60 \\
\hline & Point source & 0.013 & 7.7 & 29.8 & 1.07 & 6.63 \\
\hline & Downstream & 0.019 & 7.7 & 29.4 & 1.85 & 5.80 \\
\hline & Further Downstream & 0.018 & 7.7 & 29.4 & 2.40 & 5.30 \\
\hline
\end{tabular}

Table 4: Oxygen Sag Calculation with variable $k_{2}$

\begin{tabular}{|c|c|c|c|c|c|c|c|c|c|}
\hline Section & $\begin{array}{c}\text { Locations along River } \\
\text { Challawa } \\
\end{array}$ & $\begin{array}{c}\Delta \mathrm{t} \\
\text { (day) }\end{array}$ & $\begin{array}{c}\Delta \mathrm{t} \\
(\mathrm{min})\end{array}$ & $\mathrm{k}_{2 \mathrm{i}}$ & $\mathrm{k}_{2 \mathrm{i}+1}$ & $\frac{\left(k_{2 i+1}+k_{2 i}\right) \Delta t}{4}$ & $e^{\left(-\left(k_{1}+V_{S}\right)\right)}$ & $\mathrm{D}_{\mathrm{i}}$ & $\mathrm{D}_{\mathrm{i}+1}$ \\
\hline \multirow{3}{*}{ 䒿 } & Upstream & 0 & 26.52 & 0.140 & 0.020 & 0.259 & 0.974 & 7.40 & 7.40 \\
\hline & Point Source & 0.018 & 25.92 & 0.020 & 0.020 & 0.259 & 0.965 & 7.40 & 6.32 \\
\hline & Downstream & 0.037 & 27.36 & 0.018 & 0.018 & 0.2599 & 0.929 & 6.32 & 5.30 \\
\hline \multirow{3}{*}{ 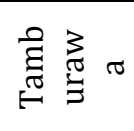 } & Upstream & 0.27 & 14.4 & 0.014 & 0.014 & 0.115 & 0.947 & 5.30 & 5.14 \\
\hline & Point Source & 0.147 & 28.8 & 0.013 & 0.013 & 0.194 & 0.745 & 5.14 & 5.93 \\
\hline & Downstream & 0.157 & 14.4 & 0.013 & 0.013 & 0.187 & 0.730 & 4.94 & 6.07 \\
\hline
\end{tabular}

$$
\mathrm{V}_{\mathrm{s}}=0.157 \mathrm{~cm} / \mathrm{min}=1.853 \mathrm{day}^{-1} . \quad \mathrm{K}_{1}+\mathrm{V}_{\mathrm{S}}=2.104 \text { day }^{-1}
$$

Table 5: Measured versus Predicted Oxygen Sag

\begin{tabular}{|c|c|c|c|c|c|}
\hline \multirow[t]{2}{*}{ Section } & \multirow[t]{2}{*}{$\begin{array}{c}\text { Locations along Challawa } \\
\text { River } \\
\end{array}$} & \multirow[t]{2}{*}{$\begin{array}{c}\text { Distance } \\
(\mathrm{km})\end{array}$} & \multirow[t]{2}{*}{$\begin{array}{c}\text { Measured oxygen deficit } \\
(\mathrm{Cs}-\mathrm{C}) \\
\end{array}$} & \multicolumn{2}{|c|}{$\begin{array}{l}\text { Computed oxygen } \\
\text { Deficit }(\mathrm{mg} / \mathrm{l})\end{array}$} \\
\hline & & & & Conventional & $\begin{array}{l}\text { With } \mathrm{v}_{\mathrm{s}} \text { and } \\
\text { variable } \mathrm{k}_{2}\end{array}$ \\
\hline \multirow{3}{*}{ 歾 } & Upstream & 0 & 7.4 & 5.60 & 7.4 \\
\hline & Point Source & 1 & 5.47 & 1.21 & 6.32 \\
\hline & Downstream & 2 & 5.50 & 0.75 & 5.30 \\
\hline \multirow{4}{*}{ 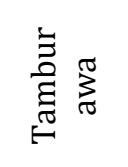 } & Upstream & 8.015 & 5.34 & 4.92 & 5.14 \\
\hline & Point Source & 8.565 & 4.60 & 5.76 & 5.93 \\
\hline & Downstream & 9.610 & 6.63 & 1.38 & 6.07 \\
\hline & Further Downstream & 10.644 & 5.30 & 11.68 & 5.45 \\
\hline
\end{tabular}

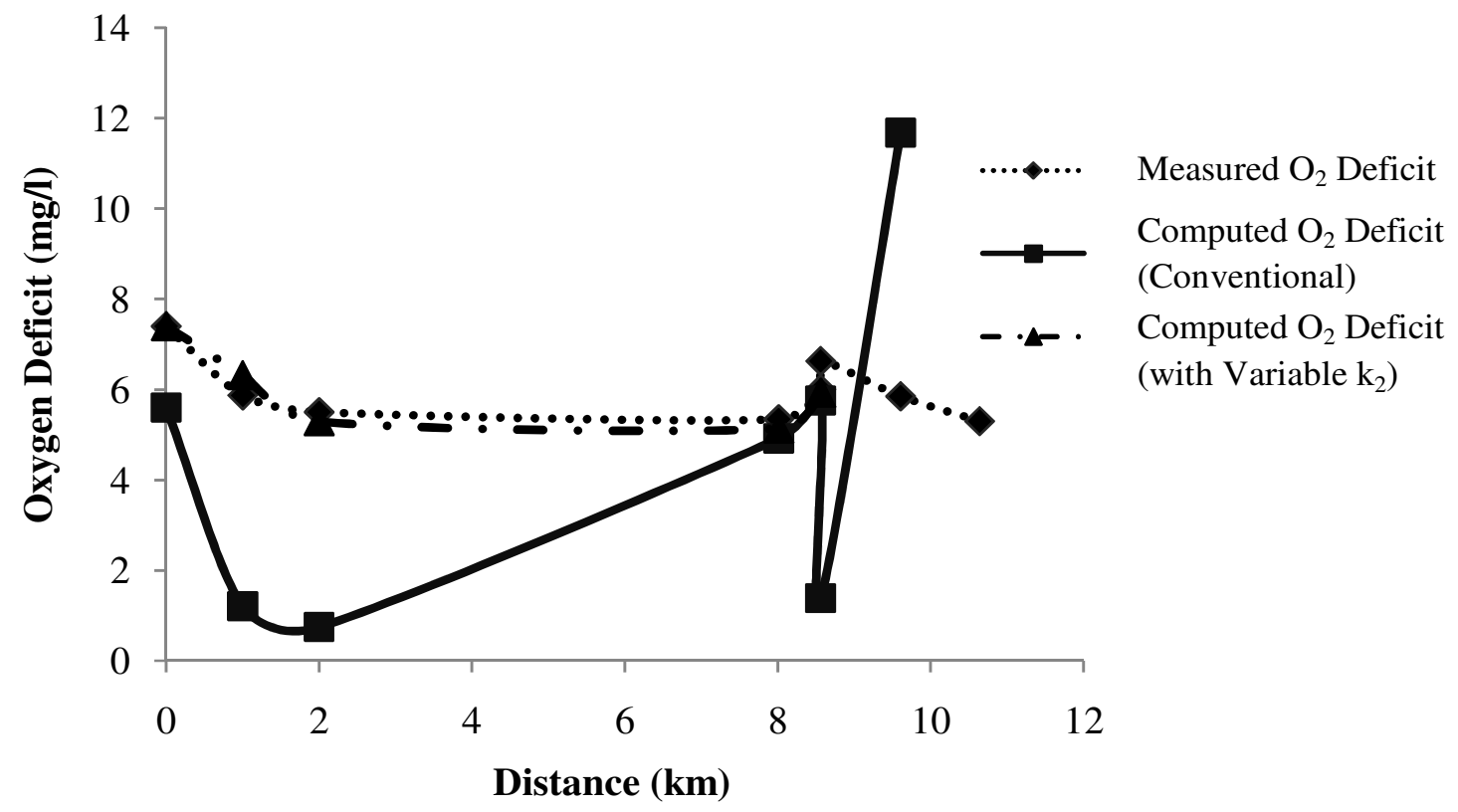

Figure 9: Oxygen Deficit against Distance 


\subsection{Verification of the two approaches}

$\mathrm{X}$ is the measured and

$\mathrm{Y}$ is the predicted

\section{Case A: Improved Approach.}

The standard error of estimate is given by $r=0.9572$;

$\mathrm{y}=1.090 \mathrm{x}-0.546$

Case B: conventional approach.

$r=0.4558 ; y=1.3756 x-416359$

Standard error $=3.0904$

\subsection{Comparison of the Conventional and Improved} Method of Determination of the Oxygen Sag Profile

From the graphs presented, it is obvious that the improved technique presented gave a profile closer to the measured oxygen deficit values than the conventional approach. The coefficients of correlation for the two approaches are respectively 0.9572 and 0.4558 . This underscores the importance of using the re-aeration coefficient values at each section and incorporating the fall velocity. In addition, the finite difference computation scheme allows for flexibility and direct incorporation of numerical values of the coefficients at every point. Hence, since the velocity also varies from section to section, using variable velocity in the computation is likely to improve the predictions further [9].

The value of the re-aeration coefficient (f) for the Challawa River varies between 0.40 day $^{-1}$ to 0.56 day $^{-1}$ which puts the river in the sluggish stream category. The self purification factor obtained showed the River Challawa as a heavily polluted stream.

\section{CONCLUSION}

The values of re-aeration coefficient, flow velocities and water depth determined at some sections in River Challawa were used to obtain for this first time for Challawa River a re-aeration equation. The high value of the coefficient of correlation is indicative of the goodness of fit of the equation to measured data. As expected from such an empirical modelling, the new equation predicted $\mathrm{k}_{2}$ values better than the other six re-aeration equations including three of them that were based on rivers in Nigeria.

The modelling was also extended to the prediction of the oxygen sag along Challawa River. Based on the deoxygenation and re-aeration constants and initial oxygen deficit, the rest of the values of the deficit from Yandanko were routed down to Tamburawa. An approach based on finite difference template was compared with the conventional analytical approach. The results of the conventional approach which ignored especially the variability of $\mathrm{k}_{2}$ along the river reaches, were compared with the improved approach, a numerical technique which incorporated the spatial variation in $\mathrm{k}_{2}$. Results showed that the incorporation of the variability of $\mathrm{k}_{2}$ in the determination of the oxygen sag equation predicted values closer to the measured values than when it was ignored.

\section{RECOMMENDATIONS}

The recommendations arising from this work are as follows:

1. The model proposed can be preferred to the existing models so far developed for use in the semi-arid areas.

2. Determination of the oxygen sag equation should be based on the spatial values rather than one time average value of the re-aeration coefficient.

\section{REFERENCES}

[1] Roberts, P.J.W., Marine Disposal, New World Wat., pp. 111-113, 1995.

[2] Agunwamba, J.C., Maduka, C.N. and Ofosaren, A.M., "Analysis of Pollution Status of Amadi Creek and its Management", Journal of Water Supply Research and Technology-AQUA 55.6., 2006, pp 427-435

[3] Ademoroti, C.M.A. "Environmental management: Case studies in industrial wastewater treatment", in Environmental issues and Management in National Development, Sada, P.O. and Odemerho, F.O., (Eds.), Evans Brothers Publishers Ltd., Nigeria, 1988.

[4] Churchill, M.A. Elmore, H.L. and Buckingham, R.A., "The prediction of stream reaeration rates", Journal of Sanitary Eng. DivisionASCE 88 (SA), pp 1-46, 1962.

[5] O'Connor, D.J. and Dobbins, W.E., "Mechanism of Reaeration in Natural Streams", Transaction of the American Society of Civil Engineers, Vol. 123, pp 641$666,1958$.

[6] Gualtieri, C. and Gualterie, P. "Statistical analysis of reaeration rate in streams", International Agricultural Engineering Conference (ICAE) 99, Pechino, China, pp. 14117, December 1999.

[7] Agunwamba, J.C., Engineering Mathematical Analysis, De-Adroit Innovation, Enugu, pp 503-504, 2007

[8] Ugbebor, J.N., Agunwamba, J.C. and Amah, V.E. (2012) Determination of reaeration coefficient $K_{2}$ for polluted streams as a function of depth, hydraulic radius, temperature and velocity. Nijotech Journal, Vol. 31, No. 2, Pp 174 - 180,

[9] Igboanugo, A.C., Ezemonye,L.I.N., Chiejine, C.M. (2013) Influence of effluent discharge and runoffs into Ikpoba River on its water quality. Nijotech Journal, Vol. 32, No. 2, pp. 294 - 303. 